\title{
Optimising physiochemical control of invasive Japanese knotweed
}

\author{
Daniel Jones $(\mathbb{D} \cdot$ Gareth Bruce • Mike S. Fowler 1 - Rhyan Law-Cooper • \\ Ian Graham - Alan Abel - F. Alayne Street-Perrott $(\mathbb{D} \cdot$ Daniel Eastwood $(\mathbb{D}$
}

Received: 15 June 2017 / Accepted: 5 February 2018/Published online: 23 April 2018

(C) The Author(s) 2018. This article is an open access publication

\begin{abstract}
Japanese knotweed, Fallopia japonica var. japonica, causes significant disruption to natural and managed habitats, and provides a model for the control of invasive rhizome-forming species. The socioeconomic impacts of the management of, or failure to manage, Japanese knotweed are enormous, annually costing hundreds of millions of pounds sterling (GBPf) in the UK alone. Our study describes the most extensive field-based assessment of $F$. japonica control treatments undertaken, testing the
\end{abstract}

Electronic supplementary material The online version of this article (https://doi.org/10.1007/s10530-018-1684-5) contains supplementary material, which is available to authorized users.

D. Jones $(\bowtie) \cdot$ G. Bruce · M. S. Fowler .

R. Law-Cooper · D. Eastwood

Department of Biosciences, Swansea University,

Singleton Park, Swansea SA2 8PP, UK

e-mail: daniel.11.jones@gmail.com

G. Bruce

e-mail: gareth@advancedinvasives.com

M. S. Fowler

e-mail: m.s.fowler@swansea.ac.uk

R. Law-Cooper

e-mail: r.p.law-cooper@swansea.ac.uk

D. Eastwood

e-mail: d.c.eastwood@swansea.ac.uk largest number of physical and/or chemical control treatments (19 in total) in replicated $225 \mathrm{~m}^{2}$ plots over 3 years. Treatments focused on phenology, resource allocation and rhizome source-sink relationships to reduce the ecological impacts of controlling $F$. japonica. While no treatment completely eradicated $F$. japonica, a multiple-stage glyphosate-based treatment approach provided greatest control. Increasing herbicide dose did not improve knotweed control, but treatments that maximised glyphosate coverage, e.g., spraying versus stem injection, and exploited phenological changes in rhizome source-sink relationships caused the greatest reduction of basal cover and stem density after 3 years. When designing management

D. Jones - G. Bruce · R. Law-Cooper

Advanced Invasives Ltd., Institute of Life Science 2, Swansea University, Singleton Park, Swansea SA2 8PP, UK

I. Graham

Complete Weed Control Ltd., Unit 16, Hurworth Road, Newton Aycliffe DL5 6UD, UK

e-mail: ian.graham@completeweedcontrol.co.uk
A. Abel
Complete Weed Control Ltd., Unit 4, Ferry Concrete Site, Off Holden Road, Leckwith, Cardiff CF11 8BS, UK
e-mail: alan.abel@completeweedcontrol.co.uk
F. A. Street-Perrott
Department of Geography, Swansea University, Singleton Park, Swansea SA2 8PP, UK
e-mail: f.a.street-perrott@swansea.ac.uk 
strategies, effective control of $F$. japonica may be achieved by biannual (summer and autumn) foliar glyphosate applications at $2.16 \mathrm{~kg} \mathrm{AE} \mathrm{ha}^{-1}$, or by annual application of glyphosate in autumn using stem injection at $65.00 \mathrm{~kg} \mathrm{AE} \mathrm{ha}^{-1}$ or foliar spray at $3.60 \mathrm{~kg} \mathrm{AE} \mathrm{ha}{ }^{-1}$. Addition of other herbicides or physical treatment methods does not improve control. This work demonstrates that considering phenology, resource allocation and rhizome source-sink relationships is critical for the control of invasive, rhizome forming species.

Keywords Field trial - Glyphosate $\cdot$ Herbicide . Invasive alien plants (IAPs) - Invasive non-native species (INNS) · Japanese knotweed · Rhizome source-sink

\section{Introduction}

Japanese knotweed (Fallopia japonica var. japonica; referred to as $F$. japonica hereon) is one of a number of herbaceous, rhizomatous, non-climbing perennial Fallopia spp., collectively referred to as Japanese knotweed sensu lato (s.l.) taxa (Bailey and Conolly 2000). Japanese knotweed s.l. are significant Invasive Alien Plants (IAPs) across economically developed countries (Bailey 2013; Lavoie 2017). Spread is primarily through asexual (clonal) dispersal, encouraged by both anthropogenic and natural disturbance processes (e.g. disturbance by floods), accelerated by suboptimal control methods and disposal of soil contaminated with knotweed rhizome (Dawson and Holland 1999; Bailey et al. 2009).

$F$. japonica is a fast-growing competitor (C-strategist; Grime 2001) that exhibits highly plastic growth responses to environmental conditions (Beerling et al. 1994). It forms rhizomes (perennating woody storage organs), that commonly accumulate late in the preceding growing season, year after year (Callaghan et al. 1981). The extensive rhizome network of $F$. japonica is concentrated in the first metre of the soil profile and may extend vertically to a depth of 4.5 and $20 \mathrm{~m}$ laterally from the main stand of aboveground growth (Beerling et al. 1994). Above and belowground (dry) biomass values reported in northern Europe (Czech Republic, Germany and UK) range from $0.75-2.53$ to $1.19-3.01 \mathrm{~kg} \mathrm{~m}^{-2}$, respectively
(Callaghan et al. 1981; Adler 1993; Brock 1995; Strašil and Kára 2010). Domination of plant communities by dense, monospecific $F$. japonica stands results from a rapid early season development from shoot clump and rhizome buds that allow pre-emptive occupation of space and resource capture (Grime 2001; Lavoie 2017). Dominance of non-native plant communities is maintained through the growing season via escape from herbivory i.e. the Enemy Release Hypothesis (ERH; Maurel et al. 2013) and direct and/or indirect allelopathy through the soil biota i.e. the mutualism facilitation hypothesis (Parepa et al. 2013; Parepa and Bossdorf 2016), while resource sharing through clonal rhizome integration may also aid competition and spread (You et al. 2014). Such invasions displace native flora, reducing floral assemblages and modify ecosystem functioning, e.g. soil nutrient cycling (Lavoie 2017). Socioeconomic impacts include high $F$. japonica control costs that amount to $£ 165.6$ million per annum in the UK alone (Williams et al. 2010).

We propose that $F$. japonica control treatments must account for the linkage between above and belowground tissues to inform the correct timing, concentration and intensity, e.g. rhizome dormancy maybe induced by aboveground herbicide application (Nkurunziza and Streibig 2001). The delivery of adequate herbicide into belowground tissues and/or depletion of rhizome reserves are hampered by substantial above and belowground biomass and a deep rhizome system that exhibits a strong seasonal change in source-sink strength.

Management of $F$. japonica in Europe and North America is predominantly chemical, based on a range of active ingredients promoted (Delbart et al. 2012; Clements et al. 2016). The principal active ingredient employed is glyphosate, an aromatic amino acid (AAA) synthesis inhibitor, though synthetic auxins and acetolactate synthase (ALS) inhibitors are also widely used (Online Resource 1, Table S1.1). Beyond this, there are a wide range of herbicide application methods recommended for knotweed control, few of which have been tested quantitatively or at an appropriate scale, despite widespread application (Table S1.2).

We therefore tested the three main approaches applied to $F$. japonica physiochemical control: physical (e.g. covering), chemical (e.g. application of herbicide) and integrated (e.g. cutting before herbicide 
spraying; Table S1.3; Child and Wade 2000). Our study combined $F$. japonica physiology (i.e. resource allocation and rhizome source-sink strength) with physical or chemical control method target (i.e. resource depletion, uptake, movement and metabolism) to develop a novel, four-stage mechanistic model to test treatment efficacy (Fig. 1). Briefly, stage 1; early season, pre knotweed emergence disruption of new aboveground growth and depletion of rhizome reserves. Stage 2, spring treatment against metabolism and growth, reducing resource acquisition. Stage 3, summer treatment at maximum height and leaf expansion, targeting the transition point where the rhizome becomes a reserve. Stage 4, late season coupling of aboveground resource translocation to the rhizome with herbicide application, maximising translocation to belowground tissues.

The primary objective of this study was to employ an evidence-based experimental approach to provide a robust, appropriately scaled field assessment of management strategies using $F$. japonica as a model for rhizome-forming IAPs. We tested 19 currently

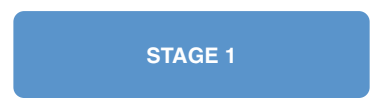

FEBRUARY - APRIL

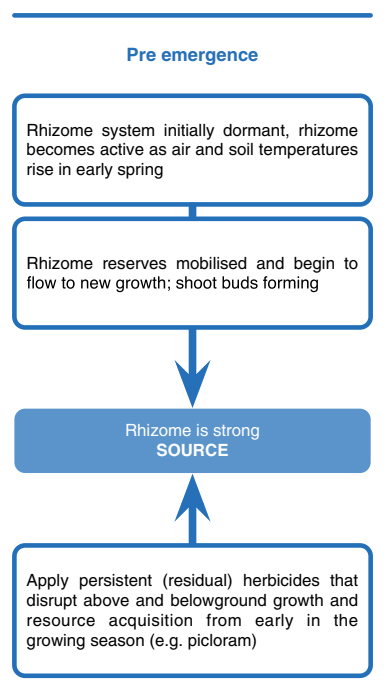

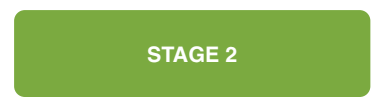

MAY - JUNE

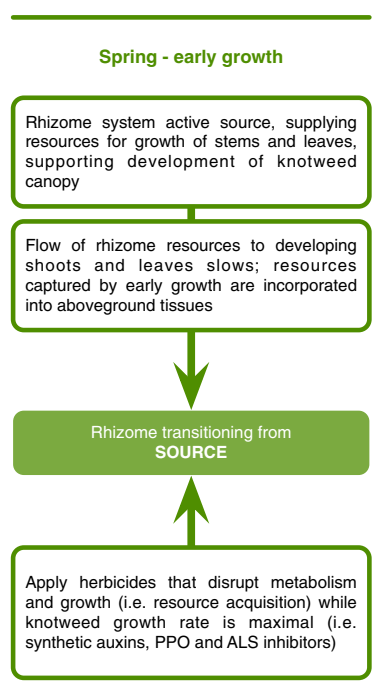

Fig. 1 Four stage mechanistic model of phenological changes in $F$. japonica growth, resource allocation and rhizome sourcesink strength during the growing season. LAI leaf area index. Note linkage of above and belowground growth processes with changes in source-sink strength and that rhizome tissue sink strength increases through the growing season from June, reaching a peak in August-November during flowering and employed control strategies for effectiveness with the aims of optimising $F$. japonica control and informing field-scale management of other IAPs. Limited spatial and temporal scales (less than 2 years) of field trials conducted to date have restricted the interpretation of control outcomes and interpretation of the mechanisms underpinning effective control (Child 1999; Skibo 2007; Delbart et al. 2012). Here we report on the most extensive and comprehensive (in terms of control treatments tested), multi-year field trials of $F$. japonica control, explicitly considering whether targeting the rhizome source-sink switch can provide more effective and sustainable $F$. japonica control, by reducing pesticide application to minimise ecological impact and maximise habitat recovery (Kettenring and Adams 2011).

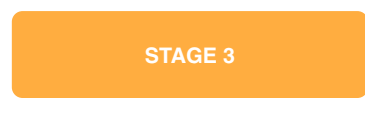

JUNE - JULY

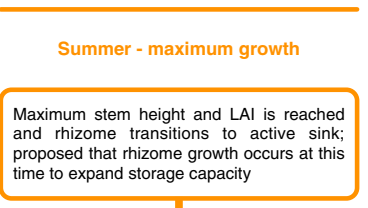
Once source-sink transition point is
reached, flow of resources from aboveground tissues to rhizome increases

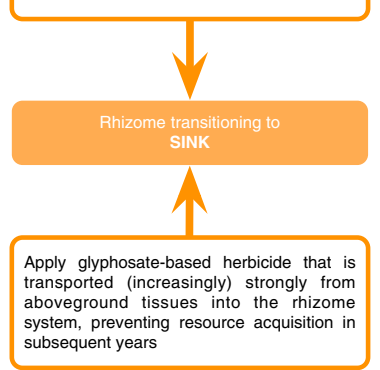

STAGE 4

AUGUST - NOVEMBER

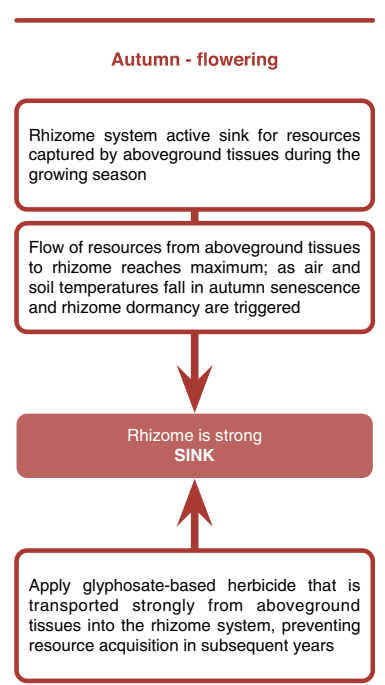

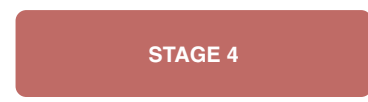

senescence. To maximise physiochemical control outcomes, physical and herbicide control treatment application should account for seasonal changes in rhizome source-sink strength. The precise timing of stages 1-4 are dependent upon local conditions and phenology may vary, impacting upon control (e.g. clones growing at higher altitude will exhibit delayed phenology, relative to lowland clones) 


\section{Methods}

Field trial site selection

Three sites in south Wales (UK) were selected (Fig. 2), with comparable geological and hydrological conditions (Online Resource 2). For the present study, control methods were applied from 2012 to 2014 at sites 1 (Lower Swansea Valley Woods) and 2 (Swansea Vale Nature Reserve) and from 2013 to 2015 at site 3 (Taffs Well).

\section{Experimental design}

Fifty-eight $225 \mathrm{~m}^{2}$ treatment and control plots were established across all three sites (Online Resource 3) and each plot was surrounded by a $1 \mathrm{~m}$ buffer zone. Physical, chemical and/or integrated treatments were applied to the whole of each treatment plot. Each treatment group (TG) was replicated in triplicate (with the exception of the covering treatment) and all sites contained one control plot. No dummy treatments were applied to the control plots as no facilities were available to clean the knapsack sprayer tank at field trial site 1 which may have resulted in application of dilute quantities of herbicide, influencing control plot response. Intra- and inter-site assignment of TGs was semi-randomised, as certain herbicide products could not legally be used near watercourses (e.g. picloram; Online Resource 2).

Annual plot assessment was undertaken in spring or autumn before control treatment application and was based on six randomly assigned $4 \mathrm{~m}^{2}$ monitoring patches within each field trial plot; pre-treatment assessment commenced in 2012. Data captured included: aboveground $F$. japonica stem density, $4 \mathrm{~m}^{2} ; F$. japonica basal percentage cover (\%) and whole plant maximum light utilisation efficiency of $\operatorname{PSII}\left(F_{v} / F_{m}\right) . F_{v} / F_{m}$ was measured using a chlorophyll fluorescence system (Handy Plant Efficiency Analyser (PEA), Hansatech Instruments, King's Lynn, UK; light intensity $3000 \mu \mathrm{mol} \mathrm{m}{ }^{-1} \mathrm{~s}^{-2}$; dark adaption time calibrated). Mean whole plant $F_{v} / F_{m}$ was derived from leaf measurements taken at 25,50 and $75 \%$ of total plant height (to reflect leaf age); six representative plants were measured within each treatment and control plot.

The above three responses to physical and chemical treatment were assessed to provide a complete picture of $F$. japonica response, accounting for absolute basal cover reduction, deformed regrowth, potential photosynthetic capacity and whole plant photosynthetic efficiency and physiological state. Importantly, basal cover measurements were made at ground level and recorded deformed regrowth, providing a good indicator of recovery from physiochemical treatments

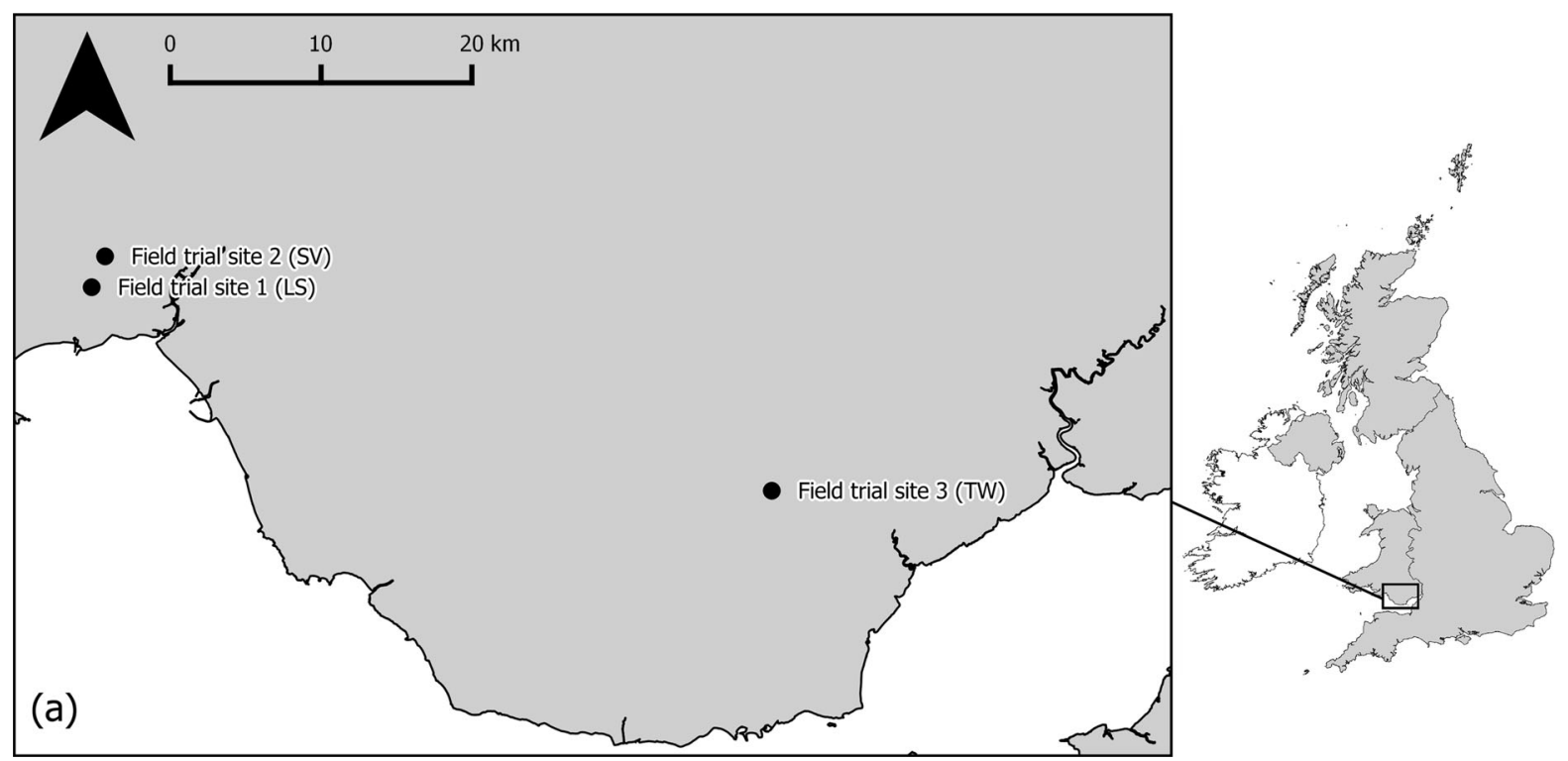

Fig. 2 Map of the study area. a Location of field trial sites in south Wales, UK. Field trial sites are assigned: $L S$ Lower Swansea Valley Woods, SV Swansea Vale Nature Reserve, $T W$ Taffs Well 
(particularly herbicide). Stem density is a stable measurement throughout the growing period and provides indication of declining aboveground investment by the plant. $F_{v} / F_{m}$ determines photosynthetic and carbon fixation efficiency, while also providing an indication of whole plant stress status (Maxwell and Johnson 2000; Dayan and Zaccaro 2012).

Herbicide product selection and control treatment timing

Herbicide product selection and application timing of the 19 treatments (Table 1) was based upon biological understanding of $F$. japonica source-sink relationships (Fig. 1) and existing, untested control treatments reported in the literature (Online Resource 1). The novel inclusion of a PPO inhibitor (HRAC Group E; WSSA Group 14) within the experimental design is the first time that the efficacy of this herbicide group has been reported for $F$. japonica control in the scientific literature (Online Resource 4, Table S4.1 provides herbicide product physical properties, fields of use, legal designations and UK inclusion date; Table S4.2 provides herbicide product and spray adjuvant manufacturers and suppliers).

Details of control treatments

\section{Herbicide control treatments}

Soil and foliar spray application (TGs al to a13, site 3) Herbicide product(s) were applied at a fixed rate ( $\mathrm{L}$ or $\mathrm{g} \mathrm{ha}^{-1}$ ), with consistent application of active ingredient(s) per unit area using a Cooper Pegler CP3 $(20$ L) Classic knapsack sprayer, fitted with a 0.75-1.5 m telescopic lance and Cooper Pegler blue flat fan nozzle (AN 1.8). All soil and foliar spray application herbicide products were applied with dye and adjuvant (Topfilm; 1.2 $\mathrm{L} \mathrm{ha}^{-1}$ ) to ensure even coverage and maximise herbicide active ingredient absorption. Herbicide products containing aminopyralid (Synero, synthetic auxin) were applied with antifoaming agent (Foam Fighter). Weather forecast information was consulted to ensure that no rain was forecast for a minimum of $8 \mathrm{~h}$ postapplication. Prior to initial soil spray herbicide application of picloram and flazasulfuron (TGs a8 and a12), aboveground $F$. japonica material from previous years, including dead stems and litter was cleared to ensure even coverage of the substratum and facilitate herbicide delivery to the rhizome and emerging shoots.

Cut and fill application (TG b1, site 3) In autumn (stage 4) of the first year of treatment, individual stems were cut at the second node above ground level, with variable rate application of 50\% v/v glyphosate solution per stem (5-10 ml dose/stem; equivalent to $87.12 \mathrm{~kg} \mathrm{AE} \mathrm{ha}{ }^{-1}$ ), using a Cooper Pegler CP3 knapsack sprayer, standard lance and green anvil nozzle (AN 1.2-anvil removed). Adjuvant $\left(1.2 \mathrm{~L} \mathrm{ha}^{-1}\right)$ was included in the tank mix to maximise active ingredient absorption. Cut stems were left in situ to prevent dispersal of $F$. japonica propagules. In subsequent years, foliar spray application of glyphosate at full label rate (FR; $3.60 \mathrm{~kg} \mathrm{AE} \mathrm{ha}{ }^{-1}$ ) was undertaken in autumn.

Stem injection application (TG cl, site 3) In autumn (stage 4) of the first year of treatment, each individual stem was injected at the second node above ground level, with variable rate application of undiluted glyphosate per stem (3-5 ml injection volume; equivalent to $65.00 \mathrm{~kg} \mathrm{AE} \mathrm{ha}{ }^{-1}$ ), using a Nomix Enviro Stem Master injection system. Adjuvant was not included in the injection system to minimise the likelihood of blockage. In subsequent years, foliar spray application of glyphosate at FR (3.60 kg AE ha ${ }^{-1}$ ) was undertaken in autumn.

\section{Integrated physiochemical control treatments}

Cutting and foliar spray application of glyphosate in autumn (TG dl, site 3) F. japonica was cut in mid growing season (summer; stage 3 ) to promote stand access and maximise re-growth. Cutting was performed using a Stihl FS-450 Professional $2.1 \mathrm{~kW}$ clearing saw and foliar spray application of glyphosate at FR (3.60 kg AE ha ${ }^{-1}$ ) was undertaken in autumn (stage 4). In subsequent years, foliar spray application of glyphosate at FR (3.60 kg AE ha ${ }^{-1}$ ) was undertaken in autumn.

Excavation (TGs $d 2$ and $d 3$, site 1) Excavation was undertaken in spring (stage 1) using a JCB 3CX backhoe loader (94 $\mathrm{cm}$ bucket, $0.3 \mathrm{~m}^{3}$ capacity) to a depth of $2.5 \mathrm{~m}$, with rhizome material roughly sorted and concentrated at the soil surface by the heavy 
Table 1 Physiochemical $F$. japonica control treatments, showing treatment group, herbicide active ingredient (a.i.), application rate, application method and timing

\begin{tabular}{|c|c|c|c|c|}
\hline $\begin{array}{l}\text { Treatment } \\
\text { group }\end{array}$ & a.i. $\left(\mathrm{g} \mathrm{L}^{-1}\right)$ & $\begin{array}{l}\text { Application rate } \\
\left(\mathrm{kg} \mathrm{AE} \mathrm{ha}{ }^{-1}\right)\end{array}$ & $\begin{array}{l}\text { Application } \\
\text { method }\end{array}$ & $\begin{array}{l}\text { Application } \\
\text { timing }\end{array}$ \\
\hline a1 & Glyphosate (360) & 3.60 & Foliar spray & Autumn \\
\hline $\mathrm{a} 2$ & Glyphosate (360) & 2.16 & Foliar spray & Autumn \\
\hline a3 & Glyphosate (360) & 2.16 & Foliar spray & $\begin{array}{l}\text { (i) Summer } \\
\text { (ii) Autumn }\end{array}$ \\
\hline a4 & $\begin{array}{l}\text { 2,4-D amine }(500) \\
\text { Glyphosate }(360)\end{array}$ & $\begin{array}{l}4.50 \\
3.60\end{array}$ & Foliar spray & $\begin{array}{l}\text { (i) Late spring } \\
\text { (ii) Autumn }\end{array}$ \\
\hline a5 & $\begin{array}{l}\text { Glyphosate }(360) \\
\text { Glyphosate }(360) \\
+2,4-\mathrm{D} \text { amine }(500)\end{array}$ & $\begin{array}{l}2.16 \\
2.16 \\
+4.50\end{array}$ & $\begin{array}{l}\text { Foliar spray } \\
\text { Foliar spray }\end{array}$ & $\begin{array}{l}\text { (i) Summer } \\
\text { (ii) Autumn }\end{array}$ \\
\hline a6 & $\begin{array}{l}\text { 2,4-D amine }(500) \\
\text { Glyphosate }(360) \\
+2,4-\mathrm{D} \text { amine }(500)\end{array}$ & $\begin{array}{l}2.80 \\
3.60 \\
+2.80\end{array}$ & $\begin{array}{l}\text { Foliar spray } \\
\text { Foliar spray }\end{array}$ & $\begin{array}{l}\text { (i) Late spring } \\
\text { (ii) Autumn }\end{array}$ \\
\hline a7 & $\begin{array}{l}\text { Glyphosate }(360) \\
+2,4-\mathrm{D} \text { amine }(500) \\
\text { Glyphosate }(360) \\
+2,4-\mathrm{D} \text { amine }(500)\end{array}$ & $\begin{array}{l}2.16 \\
+2.80 \\
2.16 \\
+2.80\end{array}$ & $\begin{array}{l}\text { Foliar spray } \\
\text { Foliar spray }\end{array}$ & $\begin{array}{l}\text { (i) Late spring } \\
\text { (ii) Autumn }\end{array}$ \\
\hline a8 & $\begin{array}{l}\text { Picloram (240) } \\
\text { Glyphosate (360) }\end{array}$ & $\begin{array}{l}2.69 \\
3.60\end{array}$ & $\begin{array}{l}\text { Soil and foliar spray } \\
\text { Foliar spray }\end{array}$ & $\begin{array}{l}\text { (i) Early spring } \\
\text { (ii) Autumn }\end{array}$ \\
\hline a9 & $\begin{array}{l}\text { Glyphosate (360) } \\
+ \text { Aminopyralid (30) and Fluroxypyr (100) } \\
\text { Glyphosate (360) }\end{array}$ & $\begin{array}{l}2.16 \\
+\underline{0.06} \text { and } \underline{0.20} \\
2.16\end{array}$ & $\begin{array}{l}\text { Foliar spray } \\
\text { Foliar spray }\end{array}$ & $\begin{array}{l}\text { (i) Late spring } \\
\text { (ii) Autumn }\end{array}$ \\
\hline a10 & $\frac{\text { Aminopyralid (30) }}{\text { Glyphosate (360) }}$ and Fluroxypyr (100) & $\frac{0.06}{3.60}$ and $\underline{0.20}$ & $\begin{array}{l}\text { Foliar spray } \\
\text { Foliar spray }\end{array}$ & $\begin{array}{l}\text { (i) Late spring } \\
\text { (ii) Autumn }\end{array}$ \\
\hline a11 & $\begin{array}{l}\text { Glyphosate }(360) \\
+ \text { Flazasulfuron } 25 \% \text { w/w } \\
\text { Glyphosate }(360)\end{array}$ & $\begin{array}{l}2.16 \\
+0.15 \\
2.16\end{array}$ & $\begin{array}{l}\text { Foliar spray } \\
\text { Foliar spray }\end{array}$ & $\begin{array}{l}\text { (i) Late spring } \\
\text { (ii) Autumn }\end{array}$ \\
\hline a12 & $\begin{array}{l}\text { Flazasulfuron } 25 \% \text { w/w } \\
\text { Glyphosate }(360)\end{array}$ & $\begin{array}{l}0.15 \\
3.60\end{array}$ & $\begin{array}{l}\text { Soil and foliar spray } \\
\text { Foliar spray }\end{array}$ & $\begin{array}{l}\text { (i) Early spring } \\
\text { (ii) Autumn }\end{array}$ \\
\hline a13 & $\begin{array}{l}\text { Glyphosate }(360) \\
+ \text { Flumioaxazin }(300) \\
\text { Glyphosate }(360)\end{array}$ & $\begin{array}{l}2.16 \\
+0.03 \\
2.16\end{array}$ & $\begin{array}{l}\text { Foliar spray } \\
\text { Foliar spray }\end{array}$ & $\begin{array}{l}\text { (i) Late spring } \\
\text { (ii) Autumn }\end{array}$ \\
\hline b1 & Glyphosate (360) & 87.12 & Cut and fill & Autumn \\
\hline $\mathrm{c} 1$ & Glyphosate (360) & 65.00 & Stem injection & Autumn \\
\hline d1 & $\begin{array}{l}\text { Cutting } \\
\text { Glyphosate (360) }\end{array}$ & $\begin{array}{l}\mathrm{N} / \mathrm{A} \\
3.60\end{array}$ & $\begin{array}{l}\text { Clearing saw } \\
\text { Foliar spray }\end{array}$ & $\begin{array}{l}\text { (i) Summer } \\
\text { (ii) Autumn }\end{array}$ \\
\hline $\mathrm{d} 2$ & $\begin{array}{l}\text { Excavation } \\
\text { Glyphosate (360) }\end{array}$ & $\begin{array}{l}\text { N/A } \\
3.60\end{array}$ & $\begin{array}{l}\text { Excavator } \\
\text { Foliar spray }\end{array}$ & $\begin{array}{l}\text { (i) Early spring } \\
\text { (ii) Autumn }\end{array}$ \\
\hline d3 & $\begin{array}{l}\text { Excavation } \\
\text { Picloram (240) } \\
\text { Glyphosate (360) }\end{array}$ & $\begin{array}{l}\text { N/A } \\
2.69 \\
3.60\end{array}$ & $\begin{array}{l}\text { Excavator } \\
\text { Soil and foliar spray } \\
\text { Foliar spray }\end{array}$ & $\begin{array}{l}\text { (i) Early spring } \\
\text { (ii) Early spring } \\
\text { (iii) Autumn }\end{array}$ \\
\hline
\end{tabular}


Table 1 continued

\begin{tabular}{lllll}
\hline $\begin{array}{l}\text { Treatment } \\
\text { group }\end{array}$ & a.i. $\left(\mathrm{g} \mathrm{L}^{-1}\right)$ & $\begin{array}{l}\text { Application rate } \\
\left.(\mathrm{kg} \mathrm{AE} \mathrm{ha})^{-1}\right)\end{array}$ & $\begin{array}{l}\text { Application } \\
\text { method }\end{array}$ & $\begin{array}{l}\text { Application } \\
\text { timing }\end{array}$ \\
\hline $\mathrm{d} 4$ & Covering & N/A & Geomembrane & Early spring \\
\hline
\end{tabular}

Underlined herbicide active ingredients indicate product mix; italicised processes represent physical components of integrated physiochemical control treatments; roman numerals represent multi-seasonal application of physiochemical control treatments. Treatment group codes are assigned: $\mathrm{a}=$ soil and foliar spray herbicide application methods; $\mathrm{b}=$ cut and fill herbicide application method; $\mathrm{c}=$ stem injection herbicide application method; $\mathrm{d}=$ integrated physiochemical control treatments. Specific timing of seasonal application was: early spring (stage 1) = March; late spring (stage 2) = May; summer (stage 3) = June; autumn (stage 4) $=$ September

equipment operator. For TG d3, this was immediately followed by soil spray application of picloram at FR (Tordon; $2.69 \mathrm{~kg} \mathrm{AE} \mathrm{ha}^{-1}$ ) in spring and for both TGs $\mathrm{d} 2$ and $\mathrm{d} 3$, foliar spray application of glyphosate at FR (3.60 $\mathrm{kg} \mathrm{AE} \mathrm{ha}^{-1}$ ) was undertaken in autumn (stage 4). In subsequent years, excavation was not performed, though soil and foliar spray application of herbicides was maintained.

\section{Physical control treatments}

Covering combined with hand pulling (TG $d 4$, site 2) Prior to covering in early spring (stage 1), aboveground $F$. japonica material from previous years was flattened and left in situ. High-density polyethylene (HDPE) geomembrane (Viqueen $^{\circledR}$ $300 \mu \mathrm{m} 1200$ gauge) was extended over the treatment area and weighted to remain in position for the duration of the experiment. Subsequent $F$. japonica growth beneath the membrane was flattened, while visible growth emerging around the covering was hand pulled and left in situ underneath the membrane, to prevent dispersal of $F$. japonica propagules. Covering was the only physical control treatment trialled, as other physical control treatments (pulling, digging and burning) were considered too costly, labour intensive and increased the risk of $F$. japonica spread.

\section{Data analysis}

F. japonica basal cover $\left(\% ; 4 \mathrm{~m}^{2}\right)$ data was arcsine transformed prior to analysis (Sokal and Rohlf 1981). We used Akaike information criteria (AIC) to select the best performing model from the following four candidate models, applied to each response variable $(y)$ for independent comparison across time $(t)$ at each site $(i)$ :

$y_{i, t}=\mathrm{DAT}_{t}$

$y_{i, t}=\mathrm{TG}_{i}$

$y_{i, t}=\mathrm{DAT}_{t}+\mathrm{TG}_{i}$

$y_{i, t}=\mathrm{DAT}_{t}+\mathrm{TG}_{i}+\mathrm{DAT}_{t} * \mathrm{TG}_{i}$

where days after treatment (DAT) is a continuous variable indicating the days after the first treatment was applied and treatment group (TG) is a categorical variable indicating the treatment group applied (including the control). The $\mathrm{DAT}_{t} * \mathrm{TG}_{i}$ term indicates the interaction term between time and treatment.

Inference was based on the parameters estimated from the best performing candidate model(s) at each site (Burnham and Anderson 2002). We used general linear (ANCOVA design) models to analyse arcsine transformed $\%$ basal cover and $F_{v} / F_{m}$ response data and compared Poisson and Negative Binomial generalised linear models (GLMs) for the stem density response data, considering AIC and goodness-of-fit statistics (comparing residual model deviance with degrees of freedom using a $\chi^{2}$-test) for the GLMs. In all cases, the Negative Binomial GLM was a more appropriate model, with the Poisson GLMs consistently being overdispersed, showing a significant difference between residual deviance and d.f. $(p<0.001)$. Therefore, only results based on the negative binomial GLMs are presented here. 
Within-site comparison of the 'best' predicted treatments at each site with other treatments and respective site controls were made based upon prior knowledge of biological and treatment processes. At site 1, TG d3 (spring dig; spring picloram FR; autumn glyphosate FR) was compared with $\mathrm{TG} \mathrm{d} 2$ and the control; at site $2 \mathrm{TG} d 4$ (covering) was compared with the control and at site 3 TG a3 (summer and autumn glyphosate half full label rate (HR) foliar spray) was compared with all other TGs and the untreated control.

All data were analysed using R v3.2.5 (The R Development Core Team 2012). The 'MASS' package (Venables and Ripley 2002) was required for negative binomial GLMs.

\section{Results}

Basal cover control response

There was no significant change over time or difference between the three sites in \% basal cover (arcsine transformed) for the untreated control plots $\left(F_{3,81}=1.54, p=0.21\right)$.

The full model (Eq. 4) predicting the effects of time (DAT) and treatment groups (TG) (including their interaction) on basal cover was selected as the best model at all sites, explaining up to $70 \%$ of the variation in the data (Table 2, Online Resource 5, Table S5.1). Basal cover decreased across all TGs, except the untreated controls at sites 1 and 3, which showed no change over time (Tables 2, S5.2-5.4; see Table S5.5 for measured initial and final mean $\%$ basal cover values for each TG at each field trial site). There were also significant differences among TGs with some treatments reducing basal cover more than others (Fig. 3a, Tables S5.2-5.4).

At site $1\left(\mathrm{R}^{2}=0.70\right)$, spring dig, spring picloram full rate (FR), autumn glyphosate FR foliar spray (TG d3) showed a faster decrease in cover over time than spring dig, autumn glyphosate FR foliar spray (TG $\mathrm{d} 2$ ), with both treatment groups performing significantly better than the untreated control (Table S5.2). At site $2\left(\mathrm{R}^{2}=0.27\right)$ the untreated control showed a significant increase in basal cover over time, while covering (d4) showed no significant change over time (Table S5.3).

At site $3\left(\mathrm{TW}, \mathrm{R}^{2}=0.61\right)$, summer and autumn glyphosate half rate (HR) foliar spray (TG a3) showed a faster decrease in basal cover over time than all other treatment groups except autumn glyphosate FR foliar spray (TG a1) and autumn glyphosate stem injection (TG c1, Fig. 3a, Table S5.4); no significant difference in basal cover decrease over time was observed between autumn glyphosate FR foliar spray (TG a1) and autumn glyphosate stem injection (TG c1).

Stem density control response

Full models examining change in stem density over time under different treatments (and their interaction) were the best models for all sites (Tables 3, S5.6-S5.9; see Table S5.10 for measured initial and final mean stem density values for each TG at each field trial site). At site 1, spring dig, spring picloram FR, autumn glyphosate FR foliar spray (TG d3) stem density
Table 2 ANCOVA results for arcsine transformed $F$. japonica $\%$ basal cover at each site, for the best model selected by AIC (AIC value for selected model; see Table S5.1 for AIC comparisons)

$D A T$ days after treatment, $T G$ treatment group

\begin{tabular}{llrllrr}
\hline Site/model fit & Model term & d.f. & Sum sq. & Mean sq. & F value & $\operatorname{Pr}(>$ F) \\
\hline 1 & DAT & 1 & 4593.8 & 4593.8 & 144.043 & $<0.001$ \\
AIC $=801.7$ & TG & 2 & 2912.7 & 1456.4 & 45.666 & $<0.001$ \\
$\mathrm{R}^{2}=0.70$ & DAT * TG & 2 & 1467.0 & 733.5 & 22.999 & $<0.001$ \\
& Residuals & 120 & 3827.0 & 31.9 & & \\
2 & DAT & 1 & 44.72 & 44.72 & 1.071 & 0.3099 \\
AIC $=209.4$ & TG & 2 & 160.61 & 160.615 & 3.847 & 0.0602 \\
$\mathrm{R}^{2}=0.27$ & DAT $*$ TG & 2 & 203.43 & 203.435 & 3.872 & 0.0360 \\
& Residuals & 27 & 1127.4 & 31.756 & & \\
3 & DAT & 1 & 35,261 & 35,261 & 1084.153 & $<0.001$ \\
AIC $=6519.0$ & TG & 2 & 9476 & 592 & 18.210 & $<0.001$ \\
$\mathrm{R}^{2}=0.61$ & DAT $*$ TG & 2 & 6445 & 403 & 12.384 & $<0.001$ \\
& Residuals & 27 & 32,264 & 33 & & \\
\hline
\end{tabular}



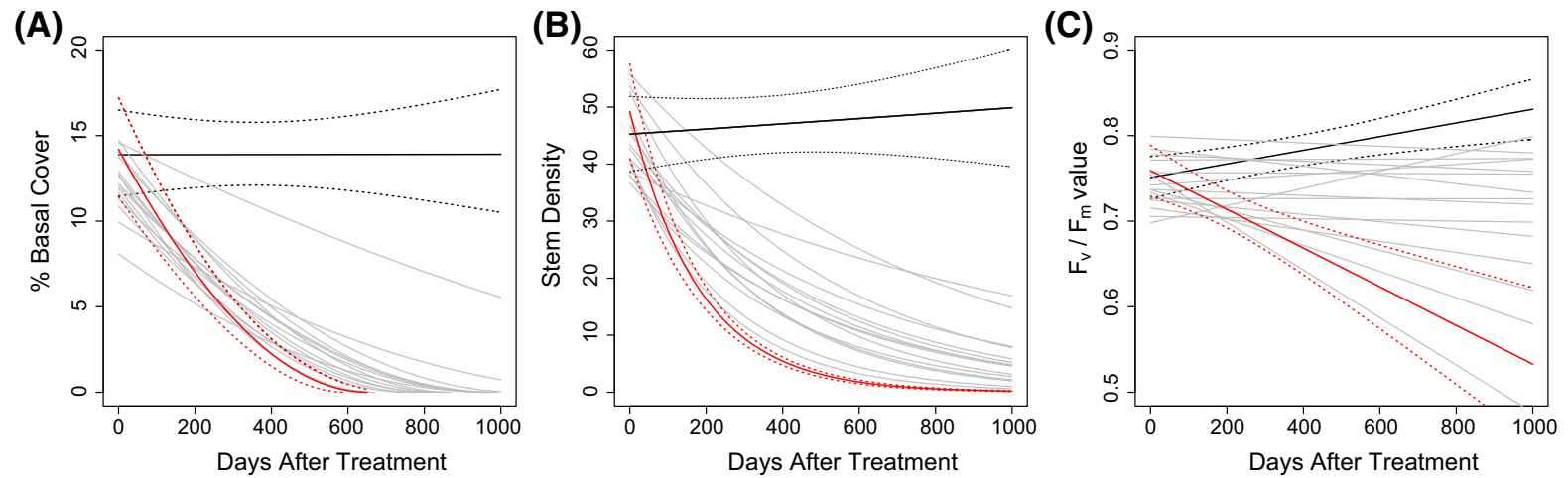

Fig. 3 Response of $F$. japonica a \% basal cover $\left(\mathrm{R}^{2}=0.61\right)$, b stem density and c light utilisation efficiency $\left(F_{v} / F_{m}\right.$, $\mathrm{R}^{2}=0.23$ ) to 16 different treatments over time at site 3 (Taffs Well). Lines show model predicted values for the effects of each different treatment group over time. Solid black lines show values from control plots (no treatment applied). Red lines show results from the best overall performing treatment group a3 (summer and autumn foliar spray application at $2.16 \mathrm{~kg} \mathrm{AE} \mathrm{ha}^{-1}$ per application; $4.32 \mathrm{~kg} \mathrm{AE} \mathrm{ha}^{-1}$ annually).
Grey lines show all other treatment groups. Dashed lines indicate $95 \%$ confidence intervals (CIs) for control and a3 treatment groups. Linear model predicted values for arcsine transformed \% basal cover were back transformed for presentation in (a), negative binomial GLM values were used in (b) and untransformed linear model values used in (c). Coefficient estimates for all treatments are given in Supplementary Tables (Online Resource 5)
Table 3 GLM (with negative binomial error distribution) results for $F$. japonica stem density $\left(4 \mathrm{~m}^{2}\right)$ at each site, for the best model selected by AIC (AIC value for selected model; see Table S5.6 for full AIC comparisons)
$D A T$ days after treatment, $T G$ treatment group

\begin{tabular}{llccccc}
\hline Site/model fit & Model term & d.f. & Deviance & Residual d.f. & Residual deviance & $\operatorname{Pr}(>\chi)$ \\
\hline 1 & NULL & & & 125 & 291.80 & \\
AIC $=1868.0$ & DAT & 1 & 24.683 & 124 & 267.12 & $<0.001$ \\
& TG & 2 & 80.166 & 122 & 186.95 & $<0.001$ \\
& DAT * TG & 2 & 58.810 & 120 & 128.14 & $<0.001$ \\
2 & NULL & & & 35 & 703.29 & \\
AIC $=340.1$ & DAT & 1 & 0.716 & 34 & 651.15 & 0.201 \\
& TG & 1 & 0.087 & 33 & 670.77 & 0.656 \\
& DAT * TG & 1 & 1.997 & 32 & 588.31 & 0.033 \\
3 & NULL & & & 1025 & 1435.6 & $<0.001$ \\
AIC $=8278.1$ & DAT & 1 & 317.33 & 1024 & 1118.2 & $<0.001$ \\
& TG & 16 & 183.38 & 1008 & 934.8 & $<0.001$ \\
\hline & DAT * TG & 16 & 154.79 & 992 & 780.1 & \\
\hline
\end{tabular}

decreased faster over time than spring dig, autumn glyphosate FR foliar spray (TG d2) or the untreated control (Table S5.7). There was no change in stem density over time at site 2 under covering (TG d4) compared to the untreated control (Table S5.8).

Stem density did not change over time for the untreated control at site 3 , but declined in all other treatments (Fig. 3b, Table S5.9). Summer and autumn glyphosate HR foliar spray (TG a3) showed significantly faster declines in stem density than any of the other treatments (Fig. 3b). Autumn glyphosate stem injection (c1) outperformed all remaining treatments except picloram-based treatments (TGs a8 and a11); however, these treatments did not perform as well as TG a3 (Table S5.9).

\section{Light utilisation efficiency control response}

Full models examining change in light utilisation efficiency over time under different treatments (and their interaction) were the best models for all sites (Tables 4, S5.11-S5.14; see Table S5.15 for measured initial and final mean $F_{v} / F_{m}$ values for each TG at each field trial site). At site 1, only spring dig, spring 
Table 4 ANCOVA results for $F$. japonica whole plant maximum light utilisation efficiency of PSII $\left(F_{v} / F_{m}\right)$ at each site, for the best model selected by AIC (AIC value for selected model; see Table S5.11 for full AIC comparisons)

$D A T$ days after treatment, $T G$ treatment group

\begin{tabular}{llrllrr}
\hline Site/model fit & Model term & d.f. & Sum sq. & Mean sq. & F value & Pr $(>$ F) \\
\hline 1 & DAT & 1 & 0.0642 & 0.0642 & 14.008 & $<0.001$ \\
AIC $=801.7$ & TG & 2 & 0.0440 & 0.0220 & 4.796 & 0.010 \\
$\mathrm{R}^{2}=0.24$ & DAT * TG & 2 & 0.0229 & 0.0114 & 2.492 & 0.088 \\
& Residuals & 92 & 0.4218 & 0.0046 & & \\
2 & DAT & 1 & 0.001 & 0.001 & 0.042 & 0.840 \\
AIC $=-13.9$ & TG & 1 & 0.149 & 0.149 & 4.878 & 0.036 \\
$\mathrm{R}^{2}=0.20$ & DAT $*$ TG & 1 & 0.050 & 0.050 & 1.633 & 0.212 \\
& Residuals & 26 & 0.793 & 0.030 & & \\
3 & DAT & 1 & 0.021 & 0.021 & 4.703 & 0.031 \\
AIC $=-2274.9$ & TG & 16 & 0.738 & 0.046 & 10.167 & $<0.001$ \\
$\mathrm{R}^{2}=0.23$ & DAT $*$ TG & 16 & 0.388 & 0.024 & 5.353 & $<0.001$ \\
& Residuals & 27 & 3.939 & 0.005 & & \\
\hline
\end{tabular}

picloram FR, autumn glyphosate FR (TG d3) showed a significant decline in $F_{v} / F_{m}$ readings over time (Table S5.12). There were no differences in the effects of different treatment groups over time on $F_{v} / F_{m}$ values at site 2 (Table S5.13). At site 3, only four TGs caused a significant reduction in $F_{v} / F_{m}$ readings over time: summer and autumn glyphosate HR foliar spray (TG a3), spring 2,4-D amine FR, autumn glyphosate FR (TG a4), summer glyphosate HR, autumn glyphosate HR and 2,4-D amine FR (TG a5) and spring glyphosate and 2,4-D amine HR, autumn glyphosate and 2,4-D amine HR (TG a7). Untreated control and a8 were both associated with an increase in $F_{v} / F_{m}$ readings over time (Fig. 3b, Table S5.14).

\section{Cross-site comparisons}

Given the lack of significant differences over time or sites for untreated control basal cover $\left(F_{3,81}=1.54\right.$, $p=0.21$, we tentatively highlight the following cross-site results for preliminary comparison (Tables S5.2-S5.4). At site 2, the estimate of spring dig, spring picloram FR, autumn glyphosate FR (TG d3) was comparable to summer and autumn glyphosate HR foliar spray at site 3 (TG a3) (Fig. S5.1, Tables S5.2 and S5.4). However, while the change in basal cover under the covering treatment at site 2 (TG d4) performed significantly better than the untreated control at site 2, which saw an increase in basal coverage (Table S5.3), covering did not lead to a significant reduction in basal cover over time and therefore performed more poorly than the physiochemical treatments employed at other sites
(Fig. S5.1). Given the differences in untreated control stem density and $F_{v} / F_{m}$ values across the sites (Fig. S5.2), we do not make any further cross-site comparisons here.

\section{Discussion}

Our study represents the largest field-based assessment of $F$. japonica control treatments to date, employing experimental designs at appropriate spatial and temporal scales needed for field-appropriate control of invasive, perennial, rhizome-forming species, such as $F$. japonica. Limited information can lead to excessive herbicide use, and costly, labour intensive and unsuccessful management strategies (Kettenring and Adams 2011). We show that later season (summer/stage 3 onwards, Fig. 1) glyphosate application provides the best control and that consideration of the above and belowground source-sink relationship increases the potential treatment window from June to October.

Through assessment of 58 treatment plots $\left(225 \mathrm{~m}^{2}\right)$ and 348 sampling plots $\left(4 \mathrm{~m}^{2}\right)$, this study aimed to account for extensive lateral extension of the rhizome from the aboveground stands and provide appropriate scale for the parameters measured. Sampling over 3 years following herbicide treatment ensured data was available for the recovery of vegetation, often lacking in other studies, which may overestimate the negative impact of treatments (Kettenring and Adams 2011). Due to difficulties in obtaining accessible field sites of sufficient scale (Kabat et al. 2006), previous 
studies have been affected by small treatment plots (Skibo 2007), geographically discrete, individual stands (Delbart et al. 2012) and split-plot designs (Child 1999). In our study, annual assessment of all treatment, control and sampling plots over 3 years (pre and post-treatment) delivered a robust and scaleappropriate dataset to support our conclusions.

Physical, chemical and integrated control treatment application was married with biological understanding of $F$. japonica. In spring (stages 1 and 2, Fig. 1), all control methods applied were intended to maximise resource depletion, through tillage (excavation), resource restriction (light; covering, PPO and ALS inhibitors) and/or disruption of above (synthetic auxins and ALS inhibitors) and belowground growth (picloram, synthetic auxin). Later season glyphosate application (stages 3 and 4, Fig. 1) aimed to maximise herbicide transit by coupling to the mass flow of photosynthates through the phloem to the rhizome (Price et al. 2002).

Greatest control of aboveground $F$. japonica growth, defined by reduced basal cover and stem density (Fig. 3a, b), was obtained using glyphosate alone, where application timing was coupled to photosynthate flow to the rhizome (Fig. 1). It is notable that stem injection required 15.07 times more glyphosate per unit area than either spray treatment and was more labour intensive to apply. In plants, glyphosate (N-(phosphonomethyl)glycine) inhibits 5-enolpyruvylshikimimate-3-phosphate synthase (EPSPS) disrupting the synthesis of aromatic amino acids (e.g. tryptophan), secondary products, plant growth substances, carbon metabolism, mineral nutrition, oxidative processes and plant-microbe-interactions (Gomes et al. 2014). Specifically, inhibition of tryptophan synthesis in the shikimate pathway, results in suppression of indole-3-acetic acid (IAA) biosynthesis (Jiang et al. 2013). Upon foliar application, glyphosate penetrates rapidly through the plant cuticle prior to slow symplastic uptake. Glyphosate then moves to metabolically active sink tissues with high expression of EPSPS, i.e. F. japonica rhizome meristems (active shoot clump and rhizome buds), while aboveground tissues display limited herbicide injury. Although there is a linear relationship between glyphosate dose and tissue concentration (Feng et al. 2003), the distribution across leaf, stem and root tissues in $F$. japonica is independent of dose and is determined by sink strength (Buschmann 1997). This contrasts with smaller, annual dicotyledonous plants that respond in a dose-dependent manner at the whole plant level (Gomes et al. 2014). Mature F. japonica leaves provide a strong source of glyphosate and its relatively slow mode of action means that translocation to active rhizome sink tissues can be achieved (Cerdeira and Duke 2006).

Glyphosate accumulation in rhizome meristems causes extensive localised cell and tissue death via blocking of IAA biosynthesis (Gomes et al. 2014). Regrowth tissue showed limited chronic stress in numerous treatment plots $\left(F_{v} / F_{m}\right)$ when compared to untreated control plants, including autumn full rate foliar spray (TG a1) (Fig. 3c, Table S6.12) suggesting that while active meristems are poisoned effectively, regrowth occurs from healthy (previously dormant) buds of low sink strength, to which lateral rhizome translocation of herbicide is limited. Sub-lethal effects of insufficient glyphosate accumulation include aboveground tissue survival within the season of herbicide application and deformed regrowth due to retention of glyphosate in (previously) active meristems in subsequent years, due to insufficient glyphosate accumulation and/or retention (Fig. 3; Feng et al. 2003; Cerdeira and Duke 2006).

Significantly reduced stem density and $F_{v} / F_{m}$ measurements recorded with summer and autumn glyphosate foliar spray application (TG a3) compared with autumn full rate foliar spray (TG a1, Fig. 3b, c) suggests translocation and poisoning of active buds from June onwards (summer/stage 3) onwards, prior to mass transit of photosynthate in autumn (stage 4). Reduced TG a3 $F_{v} / F_{m}$ measurements by the end of the field trials may demonstrate a chronic stress response resulting from disruption of mid-season rhizome expansion that limits its storage (source) capacity in subsequent years. Further research should aim to determine whether excess resource translocated in summer (stage 3) might support rhizome growth, while mass transit at stage 4 is used to store acquired resources to support growth in the following season. Interestingly, combining glyphosate and 2,4-D amine (TGs a4, 5 and 7) in summer and autumn also significantly reduced $F_{v} / F_{m}$ measurements compared with the untreated control, yet effective control of aboveground $F$. japonica growth was not recorded (Fig. 3).

The application of synthetic auxins 2,4-D amine, picloram, aminopyralid and fluroxypyr (TGs a4 to 10, 
d3), ALS inhibitor flazasulfuron (TGs a11 and 12), and PPO inhibitor flumioxazine (TG a13) did not significantly reduce long-term basal cover or stem density compared with two foliar glyphosate treatments (TG a3, Fig. 3). This poses a potential challenge for the future management of Japanese knotweed s.l. taxa: while $F$. japonica is a single female clone throughout much of the invasive range, other invasive hybrid knotweeds (particularly Fallopia $\times$ bohemica) possess greater genetic diversity (Bailey 2013). Consequently, reliance upon a single herbicide (glyphosate) may lead to resistance development in these hybrid populations. Accordingly, further research should be performed to find alternative effective herbicides to slow or avoid glyphosate resistance development in these species.

Integration of excavation with picloram and glyphosate (TG $\mathrm{d} 3$ ) showed a greater reduction in basal cover than without excavation (TG a8, Fig. 3). This was presumably through picloram suppression of active and dormant rhizome buds brought to the surface during excavation. However, TG d3 performance was comparable with summer and autumn glyphosate HR foliar spray (TG a3), despite d3's greater labour and equipment requirements and cost. Additionally, picloram was deregulated without replacement within the EU in 2015, prohibiting use over a significant part of the invasive range. Reduction in stem density caused by pre-emergence (stage 1) and mid-season (stage 2) herbicide application allows better access to stands and has the appearance of immediate $F$. japonica control. However, basal cover remains high, indicating regrowth and recovery of aboveground growth without further treatment (i.e. late season glyphosate). Therefore, stage 1 and 2 treatments may not achieve sufficient resource depletion due to significant reserves held in the above and belowground $F$. japonica biomass.

Geomembrane covering ( $\mathrm{TG} \mathrm{d} 4$ ) was the least effective control treatment in reducing the response parameters (Online Resource 6). Integrating physical control methods with glyphosate treatments did not improve $F$. japonica control compared with glyphosate alone, i.e., summer cutting and autumn glyphosate application (TG d1), spring excavation and autumn glyphosate (TG d2) and autumn cut and fill (TG b1). Summer cutting has been recommended to enhance stand access (Gover 2005) and deplete rhizome energy reserves (Child and Wade 2000). However, telescopic lance spray equipment should provide access to all but the most inaccessible $F$. japonica stands and cuttinginduced rhizome depletion has not been demonstrated empirically under field conditions. Longer-term analysis may demonstrate that excavation allows poisoning of a greater number of rhizome buds and biomass which was not detected in this 3 year study. Stem density reduction caused by autumn cut and fill treatment (TG b1) did not differ from the glyphosate spray treatments (TGs a1 and a3), despite using 20.37 times more glyphosate per unit area $(87.12 \mathrm{~kg} \mathrm{AE}$ $\left.\mathrm{ha}^{-1}\right)$. Cut and fill application is restricted to stems largely located around the rhizome crowns with a diameter that can accept the equipment nozzle; therefore, overall coverage of active buds with glyphosate is low. While localised poisoning of crown buds occurs, regrowth away from the crown is unaffected, indicating that lateral translocation of glyphosate is limited (Bromilow and Chamberlain 2000) which is compounded by the removal of the aboveground biomass that drives herbicide translocation. As such, the effect on growth is not proportional to herbicide dose- there is no evidence for a classical dose-response relationship (Streibig 2013).

Approximately $75 \%$ of active ingredients used as plant protection products (PPPs) in Europe before 1993 have been withdrawn from the market following the introduction of the Pesticide Authorisation Directive (PAD) 91/414/EEC in response to public concern and medical evidence demonstrating the harmful effects of pesticides on human and wildlife health (Hillocks 2012, 2013). In turn, less toxic or less persistent molecules have been produced (Hillocks 2013) and the herbicide production industry has withdrawn support for older molecules, as sales do not support the costs involved in further (mandated) testing and re-registration. Withdrawal of certain herbicides, such as glyphosate, without suitable replacement would compromise the ability of the amenity sector to control rhizome-forming IAPs to the detriment of the wider native biodiversity and ecosystem services.

\section{Conclusions: management of rhizome-forming IAPs}

Knowledge of herbicide mode of action, appropriate dose, application timing and coverage are the most 
important factors for successful $F$. japonica control and this is relevant to other rhizome-forming IAPs such as Gunnera spp. (Gioria and Osborne 2013) and agricultural weed species such as Convolvulus arvensis (Tautges et al. 2016). Importantly, the addition of the transitional phenological source-sink stage (summer/stage 3, Fig. 1) may increase the logistically challenging narrow autumn treatment application timeframe and further optimisation could focus on glyphosate application and its effect on rhizome biology. Though no control treatment delivered complete eradication of $F$. japonica within 3 years of the first treatment application, glyphosate applied at an appropriate dose, phenological stage (Fig. 1) and level of coverage (using foliar spray and stem injection application) was found to be the most effective control treatment. An immediate recommendation for stakeholders is to discontinue the use of other widely used herbicides for control of $F$. japonica (particularly synthetic auxins) and unnecessary physical control methods (cut and fill, summer cutting and excavation) that add equipment and labour costs and increase environmental impacts, without improving control compared to spraying alone. While we recommend glyphosate use, it is acknowledged that there is a need to identify further herbicides or control approaches to reduce the potential risk of invasive hybrid knotweed populations developing resistance to the single effective herbicide. Rhizome-forming invasive species incur long-term ecological and socioeconomic costs, while few effective management tools are available, as shown by this study. Crucially, this experiment warns of further deregulation of herbicides, such as glyphosate and picloram, without equivalent replacement will lead to the application of greater quantities of ineffective herbicide products and reduce the viability and sustainability of $F$. japonica control.

Acknowledgements We are grateful to T. Rich and J. Bailey for their advice and support, particularly in the early stages of this project. We address special thanks to G. Bowes, J. Newman, A. Skibo, and A. Gover for their extensive advice and support throughout this project. We also thank S. Hathway and D. Montagnani for supplying sites and detailed site reports, respectively and C. Hipkin and B. Osborne for helpful discussions. Finally, we would like to thank the two anonymous reviewers for their suggestions and constructive comments, which helped us to improve the manuscript. This work is part-funded by the European Social Fund (ESF) through the European Union's Convergence programme administered by the Welsh Government with Swansea University and Complete Weed Control Ltd.

Data accessibility We (I) agree to archive the data associated with this manuscript should the manuscript be accepted at https://figshare.com.

\section{Compliance with ethical standards}

Conflict of interest The authors declare that they have no conflict of interest.

Open Access This article is distributed under the terms of the Creative Commons Attribution 4.0 International License (http:// creativecommons.org/licenses/by/4.0/), which permits unrestricted use, distribution, and reproduction in any medium, provided you give appropriate credit to the original author(s) and the source, provide a link to the Creative Commons license, and indicate if changes were made.

\section{References}

Adler C (1993) Growth and dispersal strategies and associations of the neophyte Polygonum cuspidatum with special regard to mowing. Tuexenia 13:373-397

Bailey JP (2013) The Japanese knotweed invasion viewed as a vast unintentional hybridisation experiment. Heredity 110:105-110

Bailey JP, Conolly AP (2000) Prize-winners to pariahs-a history of Japanese Knotweed s.l. (Polygonaceae) in the British Isles. Watsonia 23:93-110

Bailey JP, Bímová K, Mandak B (2009) Asexual spread versus sexual reproduction and evolution in Japanese Knotweed s.l. sets the stage for the "Battle of the Clones". Biol Invasions 11:1189-1203

Beerling DJ, Bailey JP, Conolly AP (1994) Fallopia japonica (Houtt.) ronse decraene. J Ecol 82:959-979

Brock JH (1995) Technical note: standing crop of Reynoutria japonica in the autumn of 1991 in the United Kingdom. Preslia 66:337-343

Bromilow RH, Chamberlain K (2000) The herbicide glyphosate and related molecules: physicochemical and structural factors determining their mobility in phloem. Pest Manag Sci 56:368-373

Burnham KP, Anderson DR (2002) Model selection and multimodel inference: a practical information-theoretic approach, 2nd edn. Springer, New York

Buschmann MD (1997) Untersuchungen zur chemischen Bekämpfung des Japanischen Staudenknöterichs (Reynoutria japonica Houtt.) unter spezieller Berücksichtigung der Stärkespeicherung und der Translokation von Saccharose. Ph.D. thesis, Universität Hohenheim

Callaghan TV, Scott R, Whittaker HA (1981) The yield, development and chemical composition of some fastgrowing indigenous and naturalised British plant species in relation to management as energy crops. Institute of 
Terrestrial Ecology (Natural Environment Research Council), Swindon

Cerdeira AL, Duke SO (2006) The current status and environmental impacts of glyphosate-resistant crops: a review. J Environ Qual 35:1633-1658

Child L (1999) Vegetative regeneration and distribution of Fallopia japonica and Fallopia $\times$ bohemica: implications for control and management. Ph.D. thesis, Loughborough University

Child L, Wade M (2000) The Japanese knotweed manual: the management and control of an invasive weed. DPS Partnership Ltd, Burgess Hill

Clements DR, Larsen T, Grenz J (2016) Knotweed management strategies in North America with the advent of widespread hybrid Bohemian knotweed, regional differences, and the potential for biocontrol via the psyllid Aphalara itadori shinji. Invasive Plant Sci Manag 9:60-70

Dawson FH, Holland D (1999) The distribution in bankside habitats of three invasive plants in the U.K. in relation to the development of control strategies. Hydrobiologica 415:193-201

Dayan FE, Zaccaro M (2012) Chlorophyll fluorescence as a marker for herbicide mechanisms of action. Pest Biochem Physiol 102:189-197

Delbart E, Mahy G, Weickmans B, Henriet F, Crémer S, Pieret $\mathrm{N}$ et al (2012) Can land managers control Japanese knotweed? Lessons from control tests in Belgium. Environ Manag 50:1089-1097

Environment Agency (EA) (2013) Managing Japanese Knotweed on development sites the knotweed code of practice. Environment Agency, Bristol

Feng PCC, Chiu T, Sammons RD (2003) Glyphosate efficacy is contributed by its tissue concentration and sensitivity in velvetleaf (Abutilon theophrasti). Pest Biochem Physiol 77:83-91

Gioria M, Osborne BA (2013) Biological flora of the British Isles: Gunnera tinctoria. J Ecol 101:243-264

Gomes MP, Smedbol E, Chalifour A, Henault-Ethier L, Labrecque M, Lepage L et al (2014) Alteration of plant physiology by glyphosate and its by-product aminomethylphosphonic acid: an overview. J Exp Bot 65:4691-4703

Gover A (2005) Managing Japanese knotweed and giant knotweed on roadsides, factsheet 5a. Penn State, Department of Horticulture, College of Agricultural Sciences, Roadside Research Project, University Park

Grime JP (2001) Plant strategies, vegetation processes and ecosystem properties, 1st edn. Wiley, Chichester

Hillocks RJ (2012) Farming with fewer pesticides: EU pesticide review and resulting challenges for UK agriculture. Crop Prot 31:85-93

Hillocks RJ (2013) Impact of EU pesticide reduction strategy and implications for crop protection in the UK and the rest of Europe. Outlooks Pest Manag. https://doi.org/10.1564/ v24_aug_00

Humpage AJ, Bide TP (2010) The mineral resource maps of wales. British geological survey (BGS) open report OR/10/ 032

Jiang L, Jin L, Guo Y, Tao B, Qiu L (2013) Glyphosate effects on the gene expression of the apical bud in soybean (Glycine max). Biochem Biophys Res Commun 437:544-549
Kabat TJ, Stewart GB, Pullin AS (2006) Are Japanese knotweed (Fallopia japonica) control and eradication interventions effective? Centre for evidence-based conservation (CEBC) systematic review no. 21

Kettenring KM, Adams CR (2011) Lessons learned from invasive plant control experiments: a systematic review and meta-analysis. J Appl Ecol 48:970-979

Lavoie C (2017) The impact of invasive knotweed species (Reynoutria spp.) on the environment: review and research perspectives. Biol Invasions. https://doi.org/10.1007/ s10530-017-1444-y

Mallory-Smith CA, Retzinger EJ (2009) Revised classification of herbicides by site of action for weed resistance management strategies. Weed Technol 17:605-619

Maurel N, Fujiyoshi M, Muratet A, Porcher E, Motard E, Gargominy O et al (2013) Biogeographic comparisons of herbivore attack, growth and impact of Japanese knotweed between Japan and France. J Ecol 101:118-127

Maxwell K, Johnson GN (2000) Chlorophyll fluorescence-a practical guide. J Exp Bot 51:659-668

Nkurunziza L, Streibig J (2001) Carbohydrate dynamics in roots and rhizomes of Cirsium arvense and Tussilago farfara. Weed Res 51:461-468

Parepa M, Bossdorf O (2016) Testing for allelopathy in invasive plants: it all depends on the substrate! Biol Invasions 18:2975-2982. https://doi.org/10.1007/s10530-016-1189$\mathrm{Z}$

Parepa M, Schaffner U, Bossdorf O (2013) Help from under ground: soil biota facilitate knotweed invasion. Ecosphere $4: 31$

Price EAC, Gamble R, Williams GG, Marshall C (2002) Seasonal patterns of partitioning and remobilization of $14 \mathrm{C}$ in the invasive rhizomatous perennial Japanese knotweed (Fallopia japonica (Houtt.) Ronse Decraene). Evol Ecol 15:347-362

R Development Core Team (2012) R: a language and environment for statistical computing. R Foundation for Statistical Computing, Vienna, Austria. http://www.R-project.org. Accessed 20 Aug 2016

Skibo A (2007) The evaluation of selected 'POST'-applied herbicides for control of Japanese knotweed (polygonum cuspidatum syn. Fallopia japonica syn. Reynoutria japonica) and a survey and characterization of this invasive species in Delaware. Ph.D. thesis, University of Delaware

Sokal RR, Rohlf FJ (1981) Biometry: the principles and practice of statistics in biological research, 2nd edn. Freeman, San Francisco

Strašil Z, Kára J (2010) Study of knotweed (Reynoutria) as possible phytomass resource for energy and industrial utilization. J Res Appl Agric Eng 56:85-91

Streibig JC (2013) Assessment of herbicide effects. http://www. ewrs.org/et/docs/Herbicide_interaction.pdf. Accessed 23 Mar 2015

Tautges NE, Burke IC, Borrelli K, Fuerst EP (2016) Competitive ability of rotational crops with weeds in dryland organic wheat production systems. Renew Agric Food Syst. https://doi.org/10.1017/S1742170516000028

Venables WN, Ripley BD (2002) Modern applied statistics with $\mathrm{S}, 4$ th edn. Springer, New York

Vincent K, Passant N (2006) Assessment of heavy metal concentrations in the United Kingdom. The Department for 
Environment, Food and Rural Affairs (DEFRA), Welsh Assembly Government (WAG), the Scottish Executive and the Department of the Environment for Northern Ireland

Williams F, Eschen R, Harris A, Djeddour D, Pratt C, Shaw RS et al (2010) The economic cost of invasive non-native species on Great Britain. CABI, Wallingford
You W, Fan S, Yu D, Xie D, Liu C (2014) An invasive clonal plant benefits from clonal integration more than a co-occurring native plant in nutrient-patchy and competitive environments. PLoS ONE. https://doi.org/10.1371/journal. pone.0097246 